\title{
SUPERVISION OF PREDATORY PRICING ON E-COMMERCE TRANSACTIONS IN INDONESIA
}

\author{
Made Lia Indah Sari ${ }^{1}$, Dewa Gede Rudy ${ }^{2}$ \\ ${ }^{1}$ Faculty of Law, Universitas Udayana \\ 2 Faculty of Law, Universitas Udayana \\ E-mail: ${ }^{1)} \underline{\text { liaindahsari11@gmail.com, }}{ }^{2)}$ dewarudy1959@gmail.com
}

\begin{abstract}
This study aims to determine the legal arrangements for predatory pricing in e-commerce transactions in Indonesia, as well as to determine the supervision of predatory pricing in e-commerce transactions in Indonesia. The method used in this research is to use a review of the literature study known as the normative legal research method. The approach used is the case approach, the statutory approach and the legal concept approach which aims to provide a legal view of the vacuum of norm issue due to the lack of affordability of regulations that strictly regulate the eradication of predatory pricing in e-commerce transactions. The analysis technique used is descriptive technique. The predatory pricing method is getting more complex with the presence of e-commerce which is classified as part of business actors who run their business subject to the Anti-Monopoly Law. Predatory pricing in Article 20 of the Anti-Monopoly Law focuses on the intention of eliminating competition which should support the nation's economic development, so that it is contrary to the objective of protecting business competition activities. Supervision of predatory pricing action refers to the basis of the regulation contained in the Anti-Monopoly Law, so based on Article 30 and Article 31 of the law, it shows that there is attributive authority to KPPU as an independent institution to supervise and maintain the business competition climate in Indonesia. The KPPU's efforts to supervise predatory pricing in e-commerce transactions can only be carried out when it is clear that the e-commerce with the benefits is carried out in the jurisdiction of the Republic of Indonesia. If predatory pricing occurs, KPPU has the authority to take actions as outlined in Article 36 of the Anti-Monopoly Law.
\end{abstract}

Keywords: Supervision, Predatory Pricing, E-Commerce

\section{INTRODUCTION}

As technology advances, it greatly influences many sectors of the economy. It is possible for consumers in their situation to transact freely across many existing platforms because of the innovations that have been introduced (Hanim, 2014). The significance of globalization as the foundation for acceleration in the previous two decades is inseparable from this process, which significantly changed people's behavior through digital-based trade and finance (Nasution, 2009). We Are Social and Hoot Suite revealed data showing that nearly all of Indonesia's social media users prefer to make their purchases online. This can be seen in the fact that the capitalization value of online trade in Indonesia has reached a record high of USD 21 billion, or Rp. 294 trillion, over the past four years (Kompas.com, 2021; We Are Social, 2020).

With the advent of Indonesia's digital market and e-commerce, it's easy to see how modern conveniences such as being able to purchase from virtually anywhere and at any time have influenced people's purchasing habits. To put it simply, electronic commerce is a business model that promotes non-face transactions and uses electronic contracts as a means of engagement between company actors and customers. Mobile phones are the only means by which customers may read the terms and 


\section{POLICY, LAW, NOTARY AND REGULATORY ISSUES (POLRI) \\ VOLUME 1 ISSUE 1 (2022)}

conditions of their e-commerce purchases. These activities must adhere to valid rules and regulations in order to be considered a legitimate form of negotiating and actual transactions (Anjani \& Santoso, 2018). In essence, in short, e-commerce can be understood as a form of electronic-based trade in goods or services, to run an e-commerce requires the principle of business to business or business to customers (Harahap, 2018). The position of the business aspect in e-commerce places business actors to be bound by trade legal arrangements as has been enforced in the area where the trade is taking place. Especially in Indonesia, all trading activities will have the same position as a real form of trade and the regulation is found in Law Number 7 of 2014 concerning Trade. In a form of trade, business actors will also be bound by Law Number 5 of 1999 concerning the Prohibition of Monopolistic Practices and Unfair Business Competition.

The predatory pricing problem, also known as market domination by selling at a loss, is linked to the practice of e-commerce that is so free to reap benefits and drawbacks in the community. The products traded are priced at the lowest levels possible, even below the market price that Micro, Small, and Medium Enterprises (MSMEs) can achieve. The market is dominated by a huge number of trading companies, which results in predatory pricing. As a result, this will imply a state of unhealthy business behavior because it results in losses for MSMEs. Predatory pricing can be said to be an activity that is prohibited for business actors by rule of reason which allows the legal assembly to be able to think about competitive factors and determine whether or not the trade is appropriate (Syarief et al., 2021). Business players that have recently placed the lowest prices are frequently found in e-commerce transactions that make spectacular price offers in order to pique the interest of consumers. The presence of a discount supplied in conjunction with a gift away that results in a spectacular price for consumers is said to be a sort of predatory pricing that is forbidden from operating in the country of Indonesia. Predatory pricing has a complex impact because it not only results in losses for small and medium-sized enterprises (SMEs) since they are unable to compete with main competitors, but it also impacts the conditions for healthy business competition and is upheld in the form of a framework for the welfare of society.

The discussion on this legal issue has previously been described by Rezmia Febriani under the title "Impact of Selling and Loss Activities Performed by Business Actors in the Perspective of Business Competition" which describes the impact of predatory pricing activities and relates these impacts to Article 5 and Article 8 of the Anti-Monopoly Law (Febrina, 2017). Meanwhile, in I Dewa Gede Riski Manda and AA Sri Indrawati with the title "Predatory Pricing Practices for Business Actors in the Perspective of Business Competition" which focuses on discussing the legal consequences of business actors who practice selling at a loss based on the Anti-Monopoly Law (Manda \& Indrawati, 2013). In the previous 2 (two) study, it can be described that the writing with the title "Supervision of Predatory Pricing on E-Commerce Transactions in Indonesia" which will be reviewed by the author does not have the same focus of discussion in full with previous writing, this is because in this paper the author will describes the weak supervision of predatory pricing practices related to e-commerce in Indonesia. As e-commerce regulations are not fully effective in providing certainty in law enforcement against predatory pricing practices, it is necessary to formulate a regulation that provides greater legal certainty in order to optimize the supervisory function mandated by the KPPU Institution in Indonesia, which is currently being considered.

Business competition activities are monitored by an institution, namely the Business Competition Supervisory Commission (hereinafter referred to as KPPU). The mandate of the legislation attributively places the KPPU over an institution that has the right to control and take action against unfair business competition. However, referring to the definition of a business competition as stated in the Anti-Monopoly Law which regulates business persons only specifically for individuals and business corporations centered in the realm of the Republic of Indonesia law. As a result of these limitations, KPPU is only able to provide limited oversight of online trade practices and predatory pricing practices, which are frequently the result of the global market's influence on e- 
commerce companies' ability to cooperate in order to offer prices below the usual sales price. As a consequence, the author is interested in analyzing the legal regulation of e-commerce practices that use predatory pricing and the KPPU's role in monitoring the activities of e-commerce business actors with the title "PREDATORY PRICING SUPERVISION ON E-COMMERCE TRANSACTIONS IN INDONESIA"

\section{METHOD}

The following study will employ a method known as normative legal research to conduct a review of the literature. There are several approaches used, including the case approach, the legal approach, and the legal concept approach, all of which aim to provide a legal perspective on the norms vacuum created by the inability to afford regulations enforcing the abolition of predatory pricing in e-commerce transactions. Additionally, an analytical method is applied, as well as a descriptive method.

\section{RESULTS AND DISCUSSION}

\subsection{Legal Regulations Against Predatory Pricing on E-Commerce Transactions in Indonesia}

In general, predatory pricing from a legal perspective in Indonesia is known as selling at a loss. Predatory pricing is a business plan that is tried by business actors by fixing prices with relatively cheap prices for the goods or services they produce with the aim that the business will be able to foster an economic climate that is most attractive to consumers so that within a certain period of time consumers will look for goods with the cheapest price which will have an impact on the destruction of the healthy competition climate with the characteristics of a weakening of the microeconomy because it is unable to compete for profits if we jointly set the lowest possible price. At first glance, predatory pricing is a profitable thing for consumers, but if it is done regularly for a long time, it will lead to a dominant direction of business actors who dominate the market (Febrina, 2017). If it has involved business actors, then the juridical consequences that will arise are the determination of business actors to comply with the law relating to buying and selling transactions. as follows:

Business actors are discussed in Article 1 number 5 of the Anti-Monopoly Law which is stated

"A business actor is every individual or business entity, whether in the form of a legal corporation or not a legal corporation that is built and domiciled or carries out activities within the legal territory of the Republic of Indonesia, either alone or jointly through agreements, conducting various business activities in the economic field."

In the formulation of the article, it can be seen that business actors can be individuals or legal entities and simultaneously carry out legal rights and obligations to be able to comply with the regulations contained in the Anti-Monopoly Law. Economic literature and law at large have developed specific benchmarks to determine whether an industry is still carrying out predatory pricing practices or not. The Areeda and Turner literature is one of the most influential literatures. They consider that these benchmarks of practice can be observed when an industry determines prices are below its short-term marginal payout. However, because information on short-term marginal costs is hard to come by, they recommend using AVC (average variable cost) information as a proxy. A logic that forms the basis for this determination is that there has never been an industry that has made a profit when operating in a situation where the price is lower than the marginal cost of a short period of time apart from there is a need or a plan or action (Febrina, 2017).

The basis for the formation of the Anti-Monopoly Law, namely moving on to the economic upheaval in 1997 to 1998 which opened up great opportunities for unhealthy trade practices, namely the control of one or several trademarks or companies that took over the market climate. In the formulation of Article 1 number 5 of the Anti-Monopoly Law, there is an agreement clause. Based 


\section{POLICY, LAW, NOTARY AND REGULATORY ISSUES (POLRI) \\ VOLUME 1 ISSUE 1 (2022)}

on the Anti-Monopoly Law, the basis of the agreement is the binding rules which involve the rights and obligations of the parties. The juridical consequence of this bond is that there is a form of supervision from the practice of violating the agreement that has been agreed upon. Indonesia has the KPPU institution which is authorized to supervise the pace of business competition to maintain a healthy competition climate for the parties.

Business actors who will be bound by an agreement to run their business must also understand the prohibitions of the Anti-Monopoly Law, one of which is also discussed in Article 20 which explains thus:

"Business actors are prohibited from supplying goods and/or services by means of selling at a loss or setting very low prices with the intention of getting rid of or shutting down the businesses of their competitors in the relevant market so as to result in monopolistic practices and/or unfair business competition."

In accordance with Article 20 of the Anti-Monopoly Law, it prohibits business actors from supplying goods and or services by selling at a loss and fixing very low prices, as with the aim of eliminating or shutting down the businesses of their competitors in the involved market, thereby triggering monopolistic practices and unfair business competition (Febrina, 2017). Selling at loss is intended for the following purposes:

1. Shutting down the other business actors

2. Limiting competitors' movement due to very below-average pricing

3. Obtain the biggest profit because the demand for consumers is guaranteed to increase

4. Is a form of promotional strategy to introduce products and e-commerce places to shop.

In Article 20 of the Anti-Monopoly Law, the prohibited form of predatory pricing is to shut down the other business actors. A business actor can be considered to carry out the supply of goods and or services using a method of fixing a relatively cheap price if the declared value is much cheaper than the price set by other business actors. Therefore, this matter must be tried horizontal comparison. A business actor who supplies goods and or services at a relatively low price can be suspected of having the intention to eliminate or disable the business of his competitors in the relevant market, if at the specified price the level of profit to be obtained is relatively cheap from a valid interest rate.

In a market of perfect competition, the valid price level in the market is determined by the demand and request for goods or services, as well as the price created will lie on the balance between the amount of consumer demand and the quantity negotiated by producers. However, often in the market for special goods or services, there are business actors who set prices (price setters or price leaders) which are usually developing business players using the lowest cost system. That is why to see the purpose of business actors who determine prices very cheaply, it is also necessary to study the ratio of the creation of these business actors. The higher the ratio for the creation of a business actor, the longer it will be possible to keep the creation price that must be borne by the relevant business actor as low as possible. In order for it to be as low as the amount of pricing that may be offered in the involved market, creation fees must remain as low as possible. In connection with this ratio of creation, so that a business actor who supplies goods and or services at a very low price, cannot be said to intend to eliminate or kill the business of its competitors, if the business actor has a high ratio scale. Predatory pricing in fact often occurs in business actors who have a position of influence. It has been recognized in Article 25 of the Anti-Monopoly Law that:

1. One business actor or a group of business actors controls $50 \%$ (fifty percent) or more of the market share of a certain type of goods or services; or

2. Two or three business actors or groups of business actors control $75 \%$ (seventy five percent) or more of the market share of a certain type of goods or services

So, basically, the Anti-Monopoly Law recognizes the existence of predatory pricing and recognizes that dominant position will provide easy space for business actors to lower prices as low as possible. However, with regard to e-commerce, the regulation of the Anti-Monopoly Law to reach 
e-commerce is very weak. This is evidenced by the meaning of e-commerce as part of business actors which is not clearly stated in Article 1 number 5 of the Anti-Monopoly Law. E-commerce which is able to cross national borders with its extraterritorial nature, therefore, until the enforcement of the provisions on Indonesian business competition cannot be carried out for foreign business actors who carry out anti-competition outside the Indonesian national territory, even though these activities have an impact on the Indonesian economy, more precisely, if it continues to emerge that foreign ecommerce businesses that carry out anti-competition activities outside the Indonesian national region cause consequences for the Indonesian economy's market and provisions, its legal defense will be harmed due to the absence of the externality principle in the Anti-Monopoly Law.

Looking at the reality of today, different digital platforms that allow online shopping or ecommerce transactions have emerged. The existence of e-commerce in Indonesia such as Shopee, Tokopedia, JD.Id, Lazada and others often offer large discounts or in other languages commonly called "low prices" which has the potential to provide room for predatory pricing. This further strengthens the disclosure of predatory pricing indications because these shopping transactions are not only produced domestically, but also abroad. Pricing for existing discounts does not have clear legal rules, so that at a certain time the setting of discounts will easily dominate the market and potentially lead to predatory pricing that will overwhelm MSMEs (Anjani \& Santoso, 2018).

\subsection{Supervision of Business Competition Against Predatory Pricing Actions on E-Commerce Transactions in Indonesia}

The increasingly rapid development of e-commerce provides broad opportunities for equalization of existing regulations to be able to reach supervision of transactions in e-commerce (Simbolon, 2013). In the previous discussion, the position of e-commerce as a legal entity is part of business actors. A business actor can be claimed to supply goods and/or services using the trick of determining a relatively cheap price if the specified price is very cheap to use the price determined from several other business persons, therefore this must be carried out in a horizontal comparison (Susanto, 2000). In the ideal competition concept market, the price level that occurs in the market is determined by the demand and supply of goods or services, i.e. the price created will lie between the balance between the number of consumer requests and the number of producer offers. However, often in the market for goods or exclusive services, there are business actors who determine price (price setters or price leaders) which are usually developing business actors with the lowest cost pattern. Therefore, to see the intention of business actors who determine prices relatively cheaply, it is also necessary to examine the pattern of creation of related business actors.

The pattern of creating a business actor will continue to be large, and it will continue to be cheap for the creation fee that must be borne by the related business actor. The above actions are part of the supervision authorized by KPPU. In the state administration system, the institution is included in the state auxiliary organ which is part of a complementary institution. KPPU is independent, namely non-intervention and stands alone specifically to enforce business competition law. As stated in the general explanation of the Anti-Monopoly Law, that:

"In order for the implementation of this law and its implementing regulations to be effective in accordance with its principles and objectives, it is necessary to establish a Business Competition Supervisory Commission (KPPU), which is an independent institution that is independent from the influence of the government and other parties, which is authorized to supervise business competition and impose sanctions. The sanctions are in the form of administrative actions, while criminal sanctions are the authority of the court."

Based on the description, KPPU is attributively given the authority to supervise and impose sanctions. Supervision is contained in Article 35 letters $b$ and c which state: 


\section{POLICY, LAW, NOTARY AND REGULATORY ISSUES (POLRI) \\ VOLUME 1 ISSUE 1 (2022)}

b. Carry out an assessment of business activities and or actions of business actors that can lead to the formation of domination practices and or unfair business competition as regulated in Article 17 to Article 24:

c. Carry out evaluations on whether or not there is abuse of dominant position which can lead to the formation of domination practices and or unfair business competition as regulated in Articles 25 to 28 ;

If it is related to predatory pricing in e-commerce transactions, then predatory pricing actions are discussed in Article 20 of the Anti-Monopoly Law, but in relation to KPPU's supervision of ecommerce, it has not received firm legal certainty, although basically KPPU has the authority to supervise all aspects related to e-commerce with business competition, but when it comes to digital trade, there are extraterritorial limitations that require special regulations because of their complexity (Fadhilah, 2019).

The practice of the cheapest discount rates by e-commerce, restrictions need to be made by taking into account the criteria of predatory pricing. This is important to be further regulated because there are no provisions relating to uniformity of discount prices that occur on a large scale in ecommerce transactions. KPPU has the role of supervising the agreements that are formed so that they do not enter into agreements or prohibited actions. Therefore, to determine this matter, there are 2 (two) approaches used at KPPU, namely the rule of reason and per se illegal. Both principles are applied to business competition law to take into account that an action or agreement made by business actors is in accordance with or exceeds the limits of the business competition law. On the principle of per se illegal which reports that, each selected agreement or business activity is called illegal minus further justification for the consequences resulting from the agreement or business activity. On the other hand, the rule of reason principle is tried through the business competition authority agency approach to make an evaluation of the consequences of certain agreements or business activities to determine whether an agreement or activity has the character of limiting or urging competition (Fadhilah, 2019).

The Anti-Monopoly Law's requirements for business actors are still restricted to those who conduct business activities inside Indonesia's jurisdiction. KPPU is unable to take action against business players who engage in business activities outside of Indonesia's legal system (Zihaningrum, 2016).

Therefore, it is necessary to have a comprehensive regulation on business persons, so that KPPU has the duty to exercise control over not only business actors carrying out activities in Indonesia, but also business actors located outside the country, but whose business activities have an impact on business transactions within the country. KPPU's efforts in supervising predatory pricing on e-commerce transactions can only be carried out when it is clear that the e-commerce with the profits made is carried out in the jurisdiction of the Republic of Indonesia. In the event of predatory pricing, KPPU is authorized to take the following actions:

1. Receipt of reports from the public

2. Further research on allegations reported or known directly by KPPU

3. Carry out investigations and/or investigations against allegations

4. Formulate the results of investigations

5. Make calls to related parties.

\section{CONCLUSION}

Predatory pricing is specifically regulated in the Anti-Monopoly Law, which regulates the qualifications of business actors, namely individuals or legal entities acting and/or domiciled in the Republic of Indonesia's legal area, while predatory pricing is regulated as a prohibited act that alters the business competition climate to one that is unhealthy as a result of significant market dominance. The predatory pricing strategy has become more difficult as a result of the emergence of e-commerce, 
which is classified as a business actor subject to the Anti-Monopoly Law. Predatory pricing, as defined in Article 20 of the Anti-Monopoly Law, is influenced by the ability to eliminate competition that would otherwise benefit the nation's economic development, and so runs counter to the goal of protecting business competing activities.

Supervision of predatory pricing acts refers to the basis of the regulation contained in the Anti-Monopoly Law, then based on Article 30 and Article 31 of the law, it shows that the KPPU has attributive authority as an independent institution to monitor and maintain the business competition climate in Indonesia. KPPU's efforts in supervising predatory pricing on e-commerce transactions can only be carried out when it is clear that the e-commerce with the profits made is carried out in the jurisdiction of the Republic of Indonesia. In the event of predatory pricing, KPPU has the authority to take action as stated in Article 36 of the Anti-Monopoly Law.

\section{REFERENCES}

Anjani, M. R., \& Santoso, B. (2018). Urgensi Rekonstruksi Hukum E-Commerce Di Indonesia. Law Reform, 14(1). https://doi.org/10.14710/lr.v14i1.20239

Fadhilah, M. (2019). Penegakan Hukum Persaingan Usaha Tidak Sehat Oleh Komisi Pengawas Persaingan Usaha (KPPU) Dalam Kerangka Ekstrateritorial. Jurnal Wawasan Yuridika, 3(1). https://doi.org/10.25072/jwy.v3i1.217

Febrina, R. (2017). Dampak Kegiatan Jual Rugi (Predatory Pricing) Yang Dilakukan Pelaku Usaha Dalam Perspektif Persaingan Usaha. Jurnal Selat, 4(2).

Hanim, L. (2014). Perlindungan Hukum Bagi Para Pihak Dalam E-Commerce Sebagai Akibat Dari Globalisasi Ekonomi. Jurnal Pembaharuan Hukum, 1(2). https://doi.org/10.26532/jph.v1i2.1476

Harahap, D. A. (2018). PERILAKU BELANJA ONLINE DI INDONESIA: STUDI KASUS. JRMSI - Jurnal Riset Manajemen Sains Indonesia, 9(2). https://doi.org/10.21009/jrmsi.009.2.02

Kompas.com. (2021). Jumlah Pengguna Internet di Indonesia 2021. https://Tekno.Kompas.Com/Read/2021/02/23/16100057/Jumlah-Pengguna-InternetIndonesia-2021-Tembus-202-Juta

Manda, I. D. G. R., \& Indrawati, S. A. A. (2013). Praktik Jual Rugi (Predatory Pricing) Pelaku Usaha Dalam Perspektif Persaingan Usaha.

Nasution, B. (2009). Hukum Kegiatan Ekonomi I (1st ed.). Books Terrace \& Library.

Simbolon, A. (2013). Pendekatan Yang Dilakukan Komisi Pengawas Persaingan Usaha Menentukan Pelanggaran Dalam Hukum Persaingan Usaha. Jurnal Hukum Ius Quia Iustum, 20(2). https://doi.org/10.20885/iustum.vol20.iss2.art2

Susanto, A. (2000). Pengaturan Hukum Persaingan Usaha di Indonesia.

Syarief, E., Shahrullah, R. S., Jaya, F., \& Kurniawan, J. (2021). Potensi Terjadinya Persaingan Usaha Tidak Sehat pada Penggunaan Aplikasi Perdagangan Elektronik di Era Revolusi Industri 4.0. Jurnal Supremasi. https://doi.org/10.35457/supremasi.v11i1.1290

We Are Social. (2020). Report of Social Media user in Indonesia. https://wearesocial.com/blog/2020/01/digital-2020/

Zihaningrum, A. (2016). Penegakan Hukum Persekongkolan Tender Berdasarkan Pasal 22 Undang-Undang Nomor 5 Tahun 1999 tentang Larangan Praktik Monopoli dan Persaingan Usaha Tidak Sehat (Studi Putusan Komisi Pengawas Persaingan Usaha 
Nomor: 16/KPPU-L/2014 tentang Dugaan Pelanggaran dalam Pengadaan Sarana Peningkatan Mutu Pendidikan di SD/SDLB di Dinas Pendidikan Kabupaten Probolinggo). 